\title{
BONE MINERAL DENSITY AND ENDOGEN SEX STEROID HORMONE ASSOCIATION IN POSTMENOPAUSAL HEALTHY WOMEN
}

\author{
Ayten SAFAROVA $^{1}$, Halil Gursoy PALA ${ }^{1}$, Erbil DOGAN $^{1}$, N. Sinem GEZER $^{2}$ \\ ${ }^{1}$ Department of Gynecology and Obstetric, Faculty of Medicine, Dokuz Eylul University, İzmir, Turkey \\ ${ }^{2}$ Department of Radiology, Faculty of Medicine, Dokuz Eylul University, İzmir, Turkey
}

\begin{abstract}
SUMMARY
Objective: During menopause, decrease in estrogen levels as well as in androgen levels is the main cause of mineral loss in bone. In this study, we aimed to investigate the relationship between mineral density of femur neck-lumbar vertebral bones and endogen sex steroid hormone levels in postmenopausal healthy women.

Material and methods: Estradiol[E2], total testosterone[TTE], free testosterone[FTE], dehydroepiandrostenedion sulfate[DHEAS], androstenedione and sex hormone-binding globulin[SHBG] measurements were performed, lumbar(L1-L4) and femur neck T scores were calculated with dual energy x-ray absorbsiometry method in 415 postmenopausal healthy women who referred to our clinic between 2006 June and 2007 May. Intermeasurement relationships and correlations were also investigated.

Results: The mean age was 55.08 $\pm 6.74(35-82)$ years, mean lumbar vertebral T scores was $-1.23 \pm 1.36(-1,85-3,00)$,

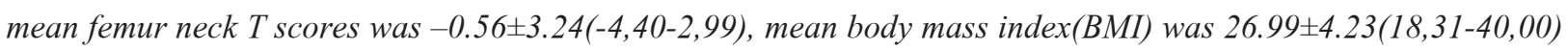
and mean years since menopause was 8.90土7.20(1,00-50,00) years. In Pearson correlation analysis, lumbar vertebral T score correlated with age $(p<0.001 ; r=-0.203)$, years since menopause $(p<0.001 ; r=-0.190), B M I(p=0.004 ; r=0.141)$ and DHEAS $(p=0.024 ; r=0.112)$. Femur neck $T$ score correlated with BMI $(p=0.028 ; r=-0.108)$ and DHEAS( $p=0.022 ; r=0.114)$. In multiregression analysis, when lumbar vertebral $T$ score was an dependent variable, it showed a significant association with body mass index $(p=0.028 ; \beta=0.131)$ and years since menopause $(p=0.048$; $\beta=-0.149)$ independently. When femur neck T score was dependent variable, it showed a significant association with $\operatorname{TTE}(p=0.001 ; \beta=0.267), \operatorname{SHBG}(p=0.001 ; \beta=-0.432)$ and free androgen index $(p=0.005 ; \beta=0.407)$ independently. Conclusion: In postmenopausal women, level of gonadal hormones is one of factors that determine osteoporosis. According to this study, androgenic parameters such as TTE, free androgen index and SHBG are associated with the bone mineral density at femur neck in postmenopausal healthy women. On other hand DHEAS has been found to be associated with bone mineral density both at femur neck and lumbar spine.
\end{abstract}

Key words: bone density, gonadal sex steroids postmenopause

Journal of Turkish Society of Obstetrics and Gynecology, (J Turk Soc Obstet Gynecol), 2011; Vol: 8 Issue: 2 Pages: 118- 24

\section{POSTMENOPOZAL SAĞLIKLI KADINLARDA KEMIK MINNERAL YOĞUNLUĞU-ENDOJEN SEKS STEROID HORMON ILIŞKISI}

\section{ÖZET}

Amaç: Bu çalışmada postmenopozal sağlıklı kadınlarda femur boynu ve lomber vertebral kemik mineral yoğunluğu ile endojen seks steroid hormon serum düzeyleri arasındaki ilişkinin araştırılması amaçlandı.

Address for Correspondence: Halil Gürsoy Pala. İnciraltı 35340 İzmir, Türkiye.

Phone.: + 90 (505 52523 32)

e-mail: gursoypala@yahoo.com

Received: 01 July 2009, revised: 16 April 2010, accepted 21 June 2010, online publication: 14.03.2011 
Gereç ve yöntemler: Haziran 2006-Mayls 2007 tarihleri arasında kliniğimize başvuran 415 postmenopozal sağllklı kadında östradiol [E2], total testosteron [TTE], serbest testosteron [FTE], dihidroepiandrostenedion sülfat [DHEAS], androstenedion ve seks hormon bağlayıcı globulin [SHBG] ölçümleri yapıldı ve dual enerji x-ray absorbsiyometri yöntemi ile lomber vertebral (L1-L4) ve femur boynu $T$ skorları hesapland. Ölçümler arası ilişki ve korelasyon araştırıldı.

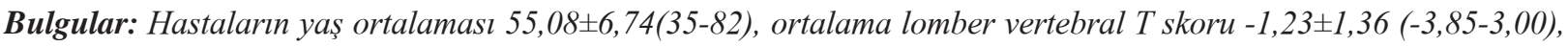

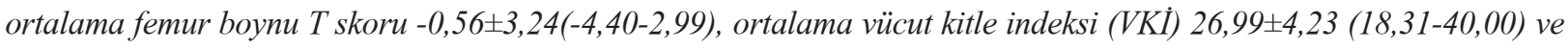

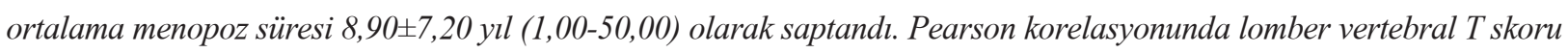
ile yaş $(p<0,001 ; r=-0,203)$, menopoz süresi $(p<0,001 ; r=-0,190)$, vücut kitle indeksi [VKİ] $(p=0,004 ; r=0,141)$ ve DHEAS $(p=0,024 ; r=0,112)$ arasinda korelasyon saptanirken; femur boynu T skoru ile sadece VKI $(p=0,028 ; r=-0,108)$ ve DHEAS $(p=0,022 ; r=0,114)$ arasında korelasyon tespit edildi. Çoklu regresyon analizinde lomber vertebral T skoru bağımlı değiş̧ken olarak alındığında, lomber vertebral T skorunu VKI $(p=0,028 ; \beta=0,131)$ ve menopoz süresinin $(p=0,048 ; \beta=-0,149)$ bağımsiz olarak etkilediği gözlendi. Femur boynu T skoru bağımlı değişken olarak alındığında ise, TTE ( $p=0,001 ; \beta=0,267), S H B G$ $(p=0,001 ; \beta=-0,432)$ ve serbest androjen indeksinin $(p=0,005 ; \beta=0,407)$ femur T skorunu bağımsı olarak etkilediği görüldü. Sonuç: Postmenopozal serum seks steroid hormon seviyeleri osteoporozu belirleyen faktörlerden birisidir. TTE, serbest androjen indeksi ve SHBG postmenopozal kadınlarda femur boynu kemik yoğunluğu ile ilişkili olmakla beraber, DHEAS hem femur boynu hem de lomber vertebral kemik mineral yoğunluğu ile ilişkilidir.

Anahtar kelimeler: gonadal seks steroidleri, kemik yoğunluğu, postmenopoz

Türk Jinekoloji ve Obstetrik Derneği Dergisi, (J Turk Soc Obstet Gynecol), 2011; Cilt: 8 Sayl: 2 Sayfa: $118-24$

\section{INTRODUCTION}

Menopause is a physiological phenomenon in the normal aging process that emerges with the cessation of ovarian functions and reveals itself with the stopping of monthly cycles. In menopause period, follicle development and cyclic estrogen secreting stops with the decrease of ovarian follicles responding to gonadotropins $^{(1,2)}$.

After approximately 35, there is anovulation, luteal phase abnormalities and and slight increase in FSH in most people(3). It is possible that these hormonal changes affect the remodeling of the bones and significant bone loss occurs in some cases even before menopause ${ }^{(4)}$.

In most cases, testosterone hormone decreases at the ratio of $25-50 \%$ in menopause ${ }^{(5)}$. In postmenopausal cases, first resource of testosterone is the androgens that are formed by transformation from dehydroepiandrosterone (DHEA). DHEA is also aromatized to estrone by transforming into androstenedion. Estrones formed this way in the adipose tissue are the main estrogens in the postmenopausal cases. Androstenedion decrease at the ratio of $50 \%$ with menopause ${ }^{(6)}$. Androstenedion and testosterone have a daily rhythm. Adrenal glands play an important role in testosterone formation. With menopause; DHEA and DHEA sulfate (DHEAS) decrease $60 \%$ and $80 \%$, respectively. About $15 \%$ of these hormones are ovary based in the reproduction periods $(1,7)$

While the most significant change in early postmenopausal period is inadequacy in estrogen hormones; adequate secretion of other steroids, androgens in particular, is important for the bones in future periods $(8)$.

Mechanism of the changes that ovary secretion inadequacy causes in the bones during menopause is complicated. Remodeling on the endosteal surface of trabecular and cortical bone, increase in bone turnover frequency are the well-known mechanisms ${ }^{(9)}$. Unless there is an imbalance between the increase in bone cycle frequency and construction-breakdown, a singly ongoing bone mass loss doesn't occur. It is known that breakdown increases in the inadequacy of estrogen ${ }^{(10)}$. Increase of the activation frequency raises the possibility of breakdown cavity formation on both surfaces of one trabecula at the same time and causes fracture in trabeculas with the combination of these cavities moving on from different sides and consequently leads to microstructural disruption(11). Androgens have a direct anabolic effect on the bone via androgen receptors ${ }^{(12)}$. It is thought that androgens cause this effect by increasing the production of growing factors like local estrogen and insulin $(13,14)$.

In this study, we aimed to investigate the relationship between mineral density of femur neck-lumbar vertebral 
bones and endogen sex steroid hormone serum levels (estradiol, total testosterone, free testosterone, DHEAS, androstenedion and sex hormone binding globulin) in postmenopausal healthy women.

\section{MATERIAL AND METHODS}

415 postmenopausal healthy women who attended to Dokuz Eylul University, Gynecology and Obstetrics Department, Menopause Polyclinic between the dates June 2006-May 2007 were enrolled in this study. Patients were underwent a gynecologic examination and weight-height measurement, cervical smear, mammography, transvaginal ultrasonography, biochemical analysis, complete blood count and complete urine analysis were performed. Detailed anamneses were obtained from the patients about menopause time, personal and family history, medicine usage, hormone treatment. Conditions of not menstruating for one year or more and serum FSH level being over $30 \mathrm{IU} / \mathrm{I}$ were demanded for postmenopause diagnosis. Patients who use medicine that would affect the bone metabolism, have a thyroid disease or malignity, have hormone replacement treatment in perimenopausal or postmenopausal period and have; fasting blood glucose $>126 \mathrm{mg} / \mathrm{dl},<$ serum creatine 1,4 mg/dl, AST-ALT $>40$ IU/1, $<$ Hb 11 mg/dl, significant leucopenia $\left(<3.000 / \mathrm{mm}^{3}\right)$ and leukocytosis $\left(>10.000 / \mathrm{mm}^{3}\right)$, thrombocytosis $\left(>400.000 / \mathrm{mm}^{3}\right.$ $\uparrow(\mathrm{tm}))$ and thrombocytopenia $\left(<150.000 / \mathrm{mm}^{3}\right)$ and hyperlipidaemia (total cholesterol $>230 \mathrm{mg} / \mathrm{dl}$ and LDL $>160 \mathrm{mg} / \mathrm{dl}, \mathrm{HDL}>40 \mathrm{mg} / \mathrm{dl}$ ) were excluded from the study.

Study was planned as cross-sectional. For BMD measurement, Dual Energy X-ray Absorbtiometry was done to the patients in the same visit and venous blood sample was taken for endogen sex steroid hormones (E2, TTE, FTE, androstenedion, DHEAS, SHBG) measurement. Informed consent form was taken from the patients enrolled in the study. Ethics committee approval was taken from Dokuz Eylul University Clinical and Laboratory Researches Committee. BMD was calculated with DEXA (General Electric LUNAR DPX) device through anterior-posterior lumbar vertebral (L1-L4) spine and non-dominant femur neck with a radiation energy of 40-70 kvolt. T score was calculated based on Turkish women at the age 20-39 and with the weight 25-100 kilograms. Osteoporosis was regarded as $\mathrm{T}$ score of $-2,5$ and below; and osteopenia as between -1 and $-2,5$.

Venous blood samples were taken between 08.00 and 10.30 in the morning fasting. E2, SHBG, TTE, DHEAS, androstenedion were measured by chemiluminescence method (Immulite, DPC, Siemens); FTE was measured by radio immunoassay method (Biosource, Gamma Counter, Cobra) and reference values were determined as $0.0-30.0 \mathrm{pg} / \mathrm{ml}$ for E2, $15-80 \mathrm{ng} / \mathrm{dl}$ for TTE, 18-114 $\mathrm{nmol} / \mathrm{L}$ for SHBG, $0.3-3.5 \mathrm{ng} / \mathrm{ml}$ for androstenedion, 0.29-3.18 pg/ml for FTE and 35-430 ng (dl for DHEAS. Free Androgen Index (FAI) was calculated as (TTE/SHBG x 100).

In the statistical analyses, correlation between BMD and endogen sex steroids, age, body mass index (BMI) and menopause time was investigated by using Pearson correlation. For the variables monitored as correlated, independent relation between the data was examined by performing a multiple regression analysis. $\mathrm{p}<0.05$ was regarded as statistically significant. SPSS 15.0 package software was used in the statistical analyses.

\section{RESULTS}

Mean age of the 415 postmenopausal patients was found as $55.08 \pm 6.74$ (35-82). Mean lumbar vertebral $\mathrm{T}$ score was determined as $-1,23 \pm 1,36(-3,85-3,00)$; mean femur neck T score as $-0,56 \pm 3,24(-4,40-2,99)$; mean body mass index (BMI) as 26,99 $\pm 4,23$ (18,31$40,00)$ and mean menopause time as $8,90 \pm 7,20$ years (1,00-50,00). According to the lumbar vertebral $\mathrm{T}$ score measurement, 53 women had osteoporotic (12,7\%); 205 women had osteopenic $(49,4 \%)$ and 157 women had normal $(37,9 \%)$ bone mineral density. According to femur neck $\mathrm{T}$ score measurement, 26 were osteoporotic (6,3\%); 220 were osteopenic (53\%) and 169 were normal (40,7\%). Demographical data and laboratory inspections of the enrolled women are summarized in Table I. 
Table I: Demographical data and laboratory inspections of the enrolled patients.

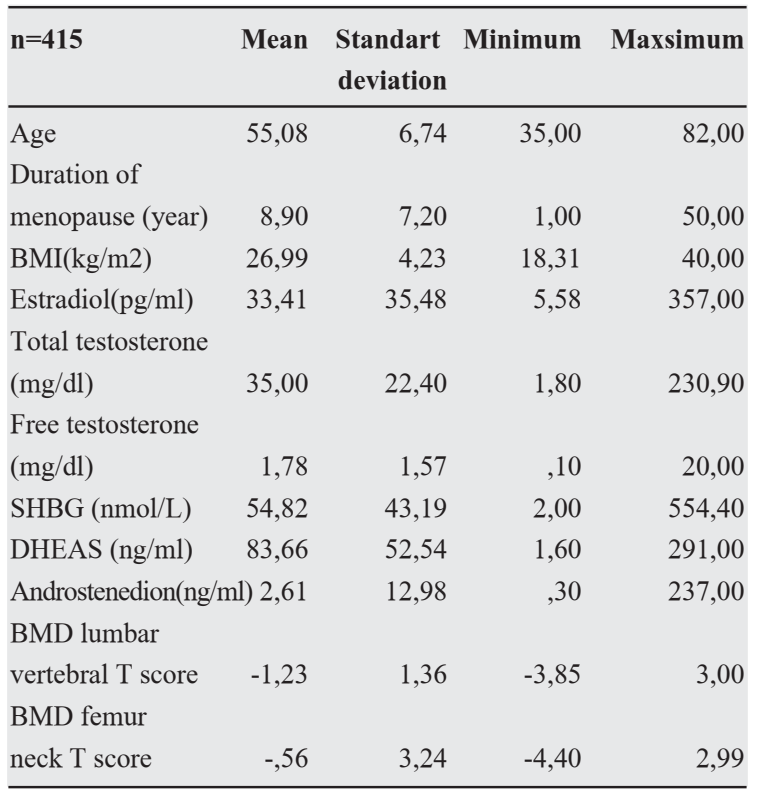

BMI- body mass index; SHBG, sex hormone binding globulin; DHEAS, dehydroepiandrosterone; $B M D$, bone mineral density.

BMI, body mass index; SHBG, sex hormone binding globulin; DHEAS, dehydroepiandrosterone; BMD, bone mineral density.

In Pearson correlation, while correlation was determined between lumbar vertebral T score and age $(\mathrm{p}<0,001$; $\mathrm{r}=$ $0,203)$, menopause time $(\mathrm{p}<0,001 ; \mathrm{r}=-0,190)$, BMI $(\mathrm{p}=0,004 ; \mathrm{r}=0,141)$ and DHEAS $(\mathrm{p}=0,024 ; \mathrm{r}=0,112)$; there was correlation between femur neck $\mathrm{T}$ score and BMI $(p=0,028 ; r=-0,018)$ and DHEAS $(p=0,022 ; r=0,114)$ only. No statistically significant correlation was determined among the other parameters (Table II).

Table II: Pearson correlation for BMD and other variables.

\begin{tabular}{lrcrc} 
& \multicolumn{2}{c}{$\begin{array}{c}\text { BMD lumbar } \\
\text { vertebral }\end{array}$} & \multicolumn{2}{c}{$\begin{array}{c}\text { BMD femur } \\
\text { neck }\end{array}$} \\
& \multicolumn{2}{c}{ T score } & \multicolumn{2}{c}{ T score } \\
& \multicolumn{2}{c}{$\mathbf{r}$} & $\mathbf{p}$ & \multicolumn{2}{c}{$\mathbf{~}$} & $\mathbf{p}$ \\
\hline Age & $-0,203$ & $<0.001^{*}$ & $-0,065$ &, 189 \\
Duration of menopause- 0,190 & $<0.001^{*}$ & 0,054 & 0,274 \\
BKI & 0,141 & $0,004^{*}$ & $-0,108$ & $0,028^{*}$ \\
Estradiol & 0,024 & 0,628 & 0,021 & 0,668 \\
Total testosterone & $-0,079$ & 0,115 & 0,075 & 0,134 \\
Free testosterone & 0,067 & 0,189 & 0,074 & 0,148 \\
DHEAS & 0,112 & $0,024^{*}$ & 0,114 & $0,022^{*}$ \\
The Multiple FAI & $-0,042$ & 0,413 & $-0,065$ & 0,208 \\
SHBG & $-0,056$ & 0,305 & $-0,101$ & 0,064 \\
Androstenedion & $-0,003$ & 0,957 & $-0,010$ & 0,849 \\
\hline
\end{tabular}

${ }^{*} p<0.05$ - significant

a- BMI, body mass index; SHBG, sex hormone binding globulin; DHEAS, dehydroepiandrosterone; $B M D$, bone mineral density; FAI, free androgen index
In the multiple regression analysis, when lumbar vertebral $\mathrm{T}$ score was taken as the dependent variable; it was monitored that BMI $(\mathrm{p}=0,028 ; \beta=0,131)$ and menopause time $(p=0,048 ; \beta=-0,149)$ affected the lumbar vertebral T score independently. Independent relation between FAI, DHEAS, patients' ages and lumbar vertebral T score wasn't determined (Table III). When femur neck $\mathrm{T}$ score was taken as the dependent variable; it was determined that TTE $(p=0,001 ; \beta=-$ $0,267)$, SHBG $(p=0,001 ; \beta=-0,149)$ and free androgen index $(p=0,005 ; \beta=0,407)$ affected the femur neck $T$ score independently. But, independent relation between DHEAS, VKI and femur neck T score wasn't monitored (Table IV).

Table III: Multiple regression analysis between lumbar vertebral bone mineral density and serum hormones, other parameters.

\begin{tabular}{lrrrr}
\hline n=415 & \multicolumn{5}{c}{ BMD lumbar vertebral } \\
& B & $\begin{array}{c}\text { Standard } \\
\text { Teviation }\end{array}$ & t & p \\
& & 0,079 & $-0,914$ & 0,117 \\
\hline Age & $-0,123$ & 0,233 & 2,333 & $0,028^{*}$ \\
BKI & 0,131 & & & \\
Menopause & & 0,218 & $-2,318$ & $0,048^{*}$ \\
time & $-0,149$ & 0,223 & 0,638 & 0,161 \\
FAI & 0,197 & 0,774 & 0,816 & 0,068 \\
DHEAS & 0,119 & &
\end{tabular}

${ }^{*} p<0.05$ - significan

a- BMI, body mass index; DHEAS, dehydroepiandrosterone; BMD, bone mineral density; FAI, free androgen index.

Table IV: Multiple regression analysis between femur neck bone mineral density and serum hormones, other parameters.

\begin{tabular}{|c|c|c|c|c|}
\hline \multirow[t]{2}{*}{$n=415$} & \multicolumn{4}{|c|}{$\begin{array}{c}\text { BMD femur neck } \\
\text { T score }\end{array}$} \\
\hline & B & $\begin{array}{l}\text { Standard } \\
\text { deviation }\end{array}$ & $\mathbf{t}$ & p \\
\hline BMI & 0,131 & 0,233 & 0,624 & 0,285 \\
\hline TTE & 0,267 & 0,218 & 2,333 & $0,001 *$ \\
\hline SHBG & $-0,432$ & 0,078 & -2.318 & $0,001 *$ \\
\hline SAI & 0,407 & 0,223 & 2,238 & $0,005^{*}$ \\
\hline DHEAS & 0,119 & 0,774 & 0,816 & 0,068 \\
\hline
\end{tabular}

${ }^{*} p<0.05$ - significant

a- BMI, body mass index; SHBG, sex hormone binding globulin; DHEAS, dehydroepiandrosterone; $B M D$, bone mineral density; FAI, free androgen index. 


\section{DISCUSSION}

Bone turnover increases secondary to the estrogen inadequacy that develops after menopause. Fast bone loss may also cause osteoporosis. Both patient's peak bone mass and bone loss after menopause are effective on osteoporosis formation. It has been stated that decrease in bone density occurs together with increase in bone resorption during postmenopausal period(15). In the studies conducted, results in which a relation between BMD and endogen E2 levels was determined $(16,17)$ and not determined $(18,19)$ were obtained. Greendale et al. carried out a study based on a large population of old women living in the society and as a result determined significant correlation between both total and bioactive E2 level, and bone mineral density in all the areas ${ }^{(20)}$. On the contrary, Yoshimura et al. concluded that serum E2 level doesn't significantly affect the bone loss amount in postmenopausal women (4).

In our study, no statistically significant relation and correlation was determined between endogen E2 levels and BMD or both lumbar vertebral and femur neck T score. The facts that our study was conducted in a single center and included a specific patient population may suggest the genetic reasons affecting BMD in terms of peak bone mass.

It is known that androgens have anabolic effects on bones. Experimental studies have shown that testosterone that functions through androgen receptors has direct or estrogen-independent effects on the bone cells ${ }^{(21)}$. Studies conducted among premenopausal women with hyperandrogen have shown that these women have higher bone mineral density and there is a positive relationship between serum testosterone levels and femur neck and lumbar vertebra bone mineral density(22). Effects of endogen androgens on BMD in postmenopausal women are less known.

In our study, an independent relation between femur neck T score and TTE, SHBG levels and FAI was determined. Lambrinoudaki et al. showed the relation between femur neck T score and TTE, FAI in their study among 884 postmenopausal healthy Greek women ${ }^{(23)}$. Also, in their 10 years prospective study conducted on 104 postmenopausal women, Wu et al. concluded that testosterone in circulation is a significant determinant of bone mineral density in various areas of the proximal femur ${ }^{(24)}$. On the contrary, in a cohort of postmenopausal women in another study, no relation was found between the bioactive testosterone and bone mineral density in lumbar vertebras and femur neck(25).

Adrenal androgens are associated with postmenopausal bone loss. DHEAS is a major adrenal androgen and decreases in serum level along with aging both in women and men. Inadequacy of DHEAS is related with decrease in bone and muscle mass, increase in lipid mass and increased atherosclerosis risk and type2 diabetes ${ }^{(26)}$.

In our study, correlation between serum levels of endogen DHEAS and lumbar vertebral and femur neck bone mineral density was determined in Pearson correlation. Findings we have obtained are in the same direction with the previous studies conducted among postmenopausal women showing that there is a relation between DHEAS and absolute bone mineral density and level of bone loss ${ }^{(27,28)}$. On the contrary, there are also studies where no positive relation was determined between DHEAS and $\operatorname{BMD}^{(12,23,29)}$.

Effect of obesity on bone mineral density in postmenopausal osteoporosis has been subject to many studies until today. It is accepted that obesity has a positive effect on BMD in general. In our study, a significant correlation between BMI and both lumbar vertebral and femur neck T scores was determined, too. Although this is thought to be an expected result, in the recent studies it has been stated that BMI is not a good BMD indicator any more ${ }^{(30)}$. The fact that it is one of the most significant variables compared to other parameters in our study appears interesting.

When the menopause duration of the patients were compared, negative correlation was monitored in only lumbar vertebral T score. While significant decrease was determined in the menopause duration and both lumbar vertebral and femur neck $\mathrm{T}$ score in the previous studies $(31,32)$, because the results were obtained crosssectionally and weren't compared to any initial value in our research, it was thought that only menopausal duration could be related with the decrease in lumbar vertebral BMD.

Postmenopausal serum sex steroid hormone levels are among the factors determining osteoporosis $(33,34)$. As a consequence, endogen estrogen levels don't affect the bone loss amount significantly in postmenopausal healthy women. On the other hand, TTE and SHBG levels are factors decreasing the bone loss especially in femur neck after menopause. Bone loss decreasing 
effect of adrenal based DHEAS is more apparent after menopause compared to that of ovarian based steroids both in femur neck and vertebra. More studies are required in order to clarify the clinical significance of sex steroids in postmenopausal circulation on fracture risk.

\section{Acknowledgements}

We'd like to thank Dr. Gul Saatli who performed the statistical control of the study.

\section{KAYNAKLAR}

1. Hurd WW, Amesse LS, Randolf Jr JF. Menopause. In Rebecca DR, Paula J, Hillard A, Berek JS eds. Novak's Gynecology. 14th edition. Los Angeles,California: Mosby Inc. 2004;p. 1109 39.

2. Rogers A, Saleh G, Hannon RA, Greenfield D, Eastell R. Circulating estradiol and osteoprotegerin as determinants of bone turnover and bone density in postmenopausal women. J Clin Endocrinol Metab 2002; 87: 4470- 5.

3. Ettinger B, Pressman A, Sklarin P, Bauer D, Cauley J, Cummings S. Associations between low levels of serum estradiol, bone density and fractures among elderly women: the study of osteoporotic fractures. J Clin Endocrinol Metab 1998; 83: 2239 43.

4. Yoshimura N, Kasamatsu T, Sakata K, Hashimoto T, Cooper C. The relationship between endogenous estrogen, sex hormonebinding globulin, and bone loss in female residents of a rural Japanese community: the Taiji study. J Bone Miner Metab 2002; 20: 303- 10

5. Rannevik G, Jeppsson S, Johnell O, Bjerre B, Laurell-Borulf Y. A longitudinal study of the perimenopausal transition: altered profiles of steroid and pituitary hormones, SHBG and bone mineral density. Maturitas 1995; 21: 103-13.

6. Wild RA, Buchanan JR, Myers C, Demers LM. Declining adrenal androgens: an association with bone loss in aging women (42625) Proc Soc Exp Biol Med 1987; 186: 355- 60

7. Jones NL, Judd HL. Menopause and postmenopause. In DeCherney AH, Nathan L eds. Current Obstetrics \& Gynecology; Diagnosis \& Treatment.7th edition. 2003: New York The McGraw-Hill Companies; p.1018- 40.

8. Munoz-Torres M, Jodar E, Quesada M, Escobar-Jimenez F. Bone mass in androgen-insensitivity syndrome: response to hormonal replacement therapy. Calcif Tissue Int 1995; 57 : 94- 6.

9. Mazess RB. On aging bone loss. Clin Orthop 1982; 165: 239-
52.

10. Kulak CAM, Bilezikian JP. Osteoporosis: preventive strategies. Int J Fertil 1998; 43: 56- 64

11. O’Neill T, Papapoulos S. Can we prevent fractures? Baillieres Clin Rheumatol 1997; 11: 565- 82

12. Zofkova I, Bahbouh R, Hill M. The pathophysiological implications of circulating androgens on bone mineral density in a normal female population. Steroids 2000;65: 857- 61 .

13. Davis SR, McCloud P, Strauss BJ, Burger H. Testosterone enhances estradiol's effects on postmenopausal bone density and sexuality. Maturitas 1995; 21: 227- 36

14. Barrett-Connor E, Goodman-Gruen D. Gender differences in insulin-like growth factor and bone mineral density association in old age: the Rancho Bernardo Study. J Bone Miner Res 1998; 13: 1343- 49.

15. Garnero P, Hausherr E, Chapuy MC, Marcelli C, Grandjean $\mathrm{H}$, Muller C et al.. Markers of bone resorption predict hip fracture in elderly women: the EPIDOS prospective study. J Bone Miner Res 1996; 11: 1531-8.

16. Fentiman IS, Wang DY, Allen DS, De Stavola BL, Moore JW, Reed MJ, et al. Bone density of normal women in relation to endogenous and exogenous oestrogens. Br J Rheumatol 1994; 33: 808- 15 .

17. Slemenda C, Longcope C, Peacock M, Hui S, Johnston CC. Sex steroids, bone mass, and bone loss: a prospective study of pre-, peri-, and postmenopausal women. J Clin Invest 1996; 97: 14- 21.

18. Spector TD, Thompson PW, Perry LA, McGarrigle HH, Edwards AC. The relationship between sex steroids and bone mineral content in women soon after the menopause. Clin Endocrinol (Oxf) 1991; 34: 37- 41 .

19. Van Beresteijn EC, Van Laarhoven JP, Smals AG. Body weight and/or endogenous estradiol as determinants of cortical bone mass and bone loss in healthy early postmenopausal women. Acta Endocrinol (Copenh) 1992; 127: 226- 30.

20. Greendale GA, Edelstein S, Barrett-Connor E. Endogenous sex steroids and bone mineral density in older women and men: the Rancho Bernardo Study. J Bone Miner Res 1997; 12: $1833-43$.

21. Kasperk CH, Wakley GK, Hierl T, Ziegler R. Gonadal and adrenal androgens are potent regulators of human bone cell metabolism in vitro. J Bone Miner Res 1997; 12: 464- 71.

22. Adami S, Zamberlan N, Castello R, Tosi F, Gatti D, Moghetti P. Effect of hyperandrogenism and menstrual cycle abnormalities on bone mass and bone turnover in young women. Clin Endocrinol (Oxf) 1998; 48: 169- 73

23. Lambrinoudaki I, Christodoulakos G, Aravantinos L, Antonion A, Rizos D, Chondros C et al.. Endogenous sex steroids and 
bone mineral density in healthy Greek postmenopausal women.

J Bone Miner Metab 2006; 24: 65- 71.

24. Wu F, Ames R, Clearwater J, Evans MC, Gamble G, Reid IR. Prospective 10-year study of the determinants of bone density and bone loss in normal postmenopausal women, including the effect of hormone replacement therapy. Clin Endocrinol (Oxf) 2002; 56: 703- 11.

25. Otremski I, Lev-Ran M, Salama R, Edelstein S. The metabolism of vitamin D3 in response to testosterone. Calcif Tissue Int 1997; 60: 485- 7

26. Watson RR, Huls A, Araghinikuam M, Chung S. Dehydroepiandrosterone and diseases of aging. Drugs Aging1996; 9: 274- 91

27. Tok EC, Ertunc D, Oz U, Camdeviren H, Ozdemir G, Dilek $\mathrm{S}$. The effect of circulating androgens on bone mineral density in postmenopausal women. Maturitas 2004; 48: 235- 42.

28. Yücel A, Noyan V, Uçar B, Sağsöz N. Postmenopozal Kadınlarda Androjenik Seks Steroidleri ile Kemik Mineral Dansitometresi Ölçümleri İlişkisi. Turkiye Klinikleri J Gynecol Obst 2005, $15: 140-5$.

29. Murphy S, Khaw KT, Sneyd MJ, Compston JE. Endogenous sex hormones and bone mineral density among community- based postmenopausal women. Postgrad Med 1992; 68: 90813.

30. Robbins J, Schott AM, Azari R, Kronmal R. Body mass index is not a good predictor of bone density: results from WHI, CHS, and EPIDOS. J Clin Densitom. 2006; 9: 329- 34.

31. Kim DJ, Khang YO, Koh JM, Shong YK, KimGS. Low normal TSH levels are associated with low bone mineral density in healthy postmenopausal women Clinical Endocrinology 2006; 64: 86- 90 .

32. Kulak J Jr, Urbanetz AA, Kulak CA, Borba VZ, Boguszewski CL. Serum androgen concentrations and bone mineral density in postmenopausal ovariectomized and non-ovariectomized women. Arq Bras Endocrinol Metabol. 2009; 53: 1033- 9.

33. Burger HG, Dudley EC, Cui J, Dennrstein L, Hopper JL. A prospective longitudinal study of serum testosterone, dehydroepiandrosterone sulfate, and sex hormone-binding globulin levels trough the menopause transition. J Clin Endocrinol Metab 2000; 85: 2832- 8 .

34. Filip R, Raszewski G. Bone mineral density and bone turnover in relation to serum leptin, alpha-ketoglutarate and sex steroids in overweight and obese postmenopausal women. Clin Endocrinol (Oxf). 2009; 70: 214- 20. 